\title{
Tinjauan Yuridis Mengenai Perangkat Undang-undang Pemilihan Umum
}

\author{
Harun Alrasid
}

\begin{abstract}
The regulations on general election together with presidential election have changed along Indonesian history. For its more than a half of a century, the way general election has varied from very multiparty - very limited party and then multiparty. For this near coming general election, the representative will be chosen directly by constituents, a new system has been introduced, this is called by open-proportional. Again, this is the time, in which president will be chosen directly by people and separately from member of parliament election. The problem is, how far this, in its implementation will give significant change for the democratization in Indonesia. This article will bring to go through this analysis.
\end{abstract}

D alam negara demokrasi, Pemilu merupakan salah satu elemen penting untuk menciptakan pemerintahan yang bersih, bertanggung jawab dan kapabel. Mekanisme Pemilu, apabila ditempuh sesuai dengan jiwa yang melahirkannya, akan melahirkan orang-orang yang terbaik. Orang-orang yang tidak memiliki kredibilitas dan kapabilitas, tentu tidak akan terpilih untuk menjadi pemimpin negara. Sehingga, kalaupun praktek Pemilu di berbagai negara berkembang dan negara transisi demokrasi ternyata masih banyak melahirkan tokohtokoh wakil rakyat ataupun presiden yang tidak memiliki kemampuan istimewa, tentu dikarenakan ada distorsi dan deviasi dalam penyelenggaraan proses Pemilu. Money politics, kolusi dan nepotisme cukup menjadi alasan yang lazim dijumpai dalam negara-negara tersebut.

Di samping itu, bagi para wakil rakyat dan pemimpin, Pemilu juga merupakan mekanisme untuk meningkatkan kinerja yang berkelanjutan. Hal itu disebabkan, dalam Pemilu yang bersih, kegagalan seorang wakil rakyat atau pemimpin yang dipilin lewat proses Pemilu, akan dinilai dengan apakah selama masa jabatan yang. diembannya tugas dan kewajiban dilaksanakan secara baik atau tidak. Sehingga, mekanimse Pemilu menjadi sebuah momentum audit yang dilakukan oleh rakyat, khususnya rakyat pemilihnya.

Atas asumsi tersebut, maka, harus senantiasa dilakukan evaluasi yuridis atas perangkat perundang-undangan Pemilu di Indonesia. Tidak lain dimaksudkan untuk meningkatkan dan menyempurnakan berbagai aspek yang berkaitan dengan Pemilu. Sehingga mekanisme Pemilu akan berjalan sebagaimana filosofi idealitasnya.

\section{Perkembangan Perundang- Undangan Pemilu}

Selama masa Orde Baru perangkat Undang-Undang dalam melaksanakan pemilihan umum (Pemilu) kecuali pada 
Pemilu 1971, ialah:

a. Undang-undang No. 3 Tahun 1975 tentang Partai Politik dan Golongan Karya;

b. Undang-undang No. 16 Tahun 1969 tentang Susunan dan Kedudukan Dewan Perwakilan Rakyat dan Dewan Perwakilan Rakyat Daerah;

c. Undang-undang No. 15 Tahun 1969 tentang Pemilihan Umum Anggotaanggota Badan Permusyawaratan/ Perwakilan Rakyat.

Ketiga Undang-undang tersebut diterapkan pada Pemilu 1971, 1982, 1987, 1992, dan terakhir kali pada Pemilu 1997.

Setelah berakhimya periode Orde Baru, yaitu dengan berhentinya Presiden Soeharto pada 21 Mei 1998, dan dimulainya era reformasi, para elit politik menganggap bahwa Pemilu yang dilaksanakan pada masa Orde Baru tidak mempunyai legitimasi Politik sebab melanggar Pasal 28 UUD 1945 yang mengatur tentang kebebàsan berserikat dan berkumpul. Meskipun asas LUBER (Langsung Umum Bebas dan Rahasia) senantiasa dicanangkan sebagai asas Pemilu, namun dalam realitanya, Pemilu yang terjadi sangat jauh dari asas kebebasan dan kerahasiaan. Menjelang dilengserkannya Soeharto, kasus kuningisasi (baca: Golkarisasi) menjadi fenomena yang sangat umum di berbagai daerah. Munas partai politik yang menjadi rival dari Golkar, senantiasa menimbulkan konflik internal dikarenakan seakan ada 'pemaksaan' masuknya orang-orang yang dinilai tidak loyal terhadap partai..

Maka kemudian, dengan tumbangnya rezim Orde Baru, tercapai konsensus nasional bahwa perlu diadakan Pemilu yang dipercepat (dari 2001 menjadi 1999), yang pesertanya ditambah dengan partai politik baru.
Untuk tujuan itu, berbagai peraturan perundangan yang berkaitan dengan Pemilu harus diperbaharui. Dalam waktu yang relatif singkat, perubahan dilakukan. Pemerintah dan DPR (hasil Pemilu 1997) menghasilkan perangkat Undang-undang yang baru, yaitu:

a. Undang-undang No 2 Tahun 1999 tentang Partai Politik;

b. Undang-undang No. 4 Tahun 1999 ". intang Susunan dan Kedudukan. Majelis Permusyawaratan Rakyat, Dewan Perwakilan Rakyat dan Dewan Perwakilan Rakyat Daerah;

c. Undang-undang No. 3 Tahun 1999 tentang Pemilihan Umum.

Dengan melihat apa yang dihasilkan tersebut di atas, ada dua kesimpulan yang dapat ditarik. Pertama, Pembuat Undangundang meneruskan saja ketiga Undangundang yang diwariskan oleh Orde Baru dengan hanya mengubah substansinya. Padahal, sebenarnya ada alternatif lain yang bisa ditempuh, yaitu soal susunan (dan kedudukan) dan pemilihan anggota badan perwakilan rakyat dapat diatur daiam "satu" Undang-undang, seperti yang terjadi pada masa Republik Pertama (17 Agustus 1945 - 27 Desember 1949), yaitu UU. No. 27 Tahun 1948 tentang Sususnan Dewan Perwakilan Rakyat dan Pemilihan Anggotanya.

Kedua, Pembuat Undang-undang mengatur tentang susunan MPR, DPR, dan DPRD, demikian pula tentang pemilihan anggotenya, secara sekaligus. Sedangkan pembuat Undang-undang pada masa Republik Pertama mengatur tentang susunan dan pemilihan anggota "satu" badan perwakilan saja, yaitu Dewan Ferwakilan Rakyat (pusat).

Perlu diketahui bahwa pada masa Republik Ketiga (17 Agustus 1950 - 5 Juli 1959), soal pemilihan anggota DPRD diatur secara tersendiri, yaitu dengan UU No. 19 
Tahun 1956.tentang pemilihan anggota DPR Daerah. Jadi, kalau UUD 1945 (pra Amendemen) mau dilaksanakan secara mumi oleh pembuat Undang-undang, maka setiap lembaga perwakilan, baik di pusat maupun di daerah, diatur dengan Undangundang tersendiri: MPR berdasarkan Pasal 2, ayat (1), DPR berdasarkan Pasal 19, ayat (1), dan DPRD berdasarkan Pasal 18.

Kalau kita bandingkan dengan beberapa negara lain, ada hal yang menarik yang bisa diambil dari proses Pemilu. Di Australia misalnya, penulis menyaksikan Pemilu 1998 di Australia yang dipilih hanya anggota Senat dan DPR (pusat). Hal itu menunjukkan adanya pengaturan tersendiri bagi anggota Senat dan DPR (pusat).

Dalam kaitannya dengan kelemahan tersebut, menjadi urgen untuk ditegaskan di sini bahwa memang menjadi tugas para pakar dalam bidang Ilmu Hukum untuk memberikan pilihan-pilihan (altemative thinking) bagi para pengambil keputusan politik. Sehingga, dalam membuat undang-undang akan lebih sesuai dengan tuntutan perkembangan kenegaraan, namun tetap menjaga konsistensi dengan ketentuan pada Undang-Undang Dasar.

Paket Undang-undang Pemilu 1999, yaitu UU No 2 tahun 1999 tentang Parpol, UU No 4 Tahun 1999 tentang Susduk, dan UU No. 3 Tahun 1999 tentang Pemilu ternyata hanya diterapkan satu kali, seperti juga halnya dengan UU No. 7 Tahun 1953 tentang Pemilihan Anggota konstituante dan Anggota Dewan Perwakilan Rakyat yang hanya diterapkan pada Pemilu 1955.

Untuk menghadapi Pemilu 2004, Presiden dan DPR (hasil Pemilu 1999) membentuk paket Undang-undang Pemilu yang baru, sebagai pelaksanaan Amandemen Pertama UUD 1945, yaitu UU No. 31 Tahun 2002 tentang Partai Politik,
UU No. 22 Tahun 2003 tentang Susunan dan Kedudukan MPR, DPR, DPD, dan DPRD, dan UU No. 12 Tahun 2003 tentang Pemilihan Anggota DPR, DPD, dan DPRD. Ditambah satu lagi, yaitu UU No. 23 Tahun 2003 tentang Pemilihan Umum Presiden dan wakil Presiden.

\section{Pemilihan Presiden dan Wakil Presiden}

Pemilihan presiden yang diatur dalam UU No.23 Tahun 2003 tersebut merupakan masalah yang benar-benar baru bagi bangsa Indonesia. Pemilu saat ini akan memulai sebuah babakan sejarah baru di mana presiden dan wakil presiden akan dipilih secara langsung oleh rakyat, bukan lagi oleh Majelis Permusyawaratan Rakyat sebagaimana biasanya.

Sejarah pemilihan presiden di Indonesia mencatat, bahwa pemilihan langsung pada Pemilu kali ini merupakan perkembangan yang sangat besar. Dalam sejarah ketatanegaraan Indonesia, pertama kali terjadi pemilihan presiden adalah pada tanggal 18 Agustus 1945, dan yang kedụa kali pada tanggal 16 Desember 1949. Pada kedua pemilihan tersebut, Ir Soekarno terpilih secara aklamasi. Juga pada pemilihan presiden oleh MPR selama Orde Baru, Jenderal Soeharto terpilih secara aklamasi.

Baru pada tanggal 20 Oktober 1999 , rakyat Indonesia menyaksikan pemilihan presiden dalam arti kata yang sebenarnya, di mana terdapat lebih dari satu calon, yaitu K.H. Abdurrahman Wahid, Ketua Umum Pengurus Nahdlatul Ulama, yang duduk di MPR sebagai Fraksi Utusan Golongan. Calon kedua ialah Megawati Soekarno Putri, puteri presiden pertama dan Ketua Umum Partai Demokrasi Indonesia Perjuangan (PDIP). 
Dari 700 orang anggota MPR, yang hadir ialah 691 orang dan hasil pemungutan suara ialah sebagai berikut, Abdurrahman Wahid 373 suara, Megawati Soekarnoputri 313 suara, abstain 5 suara. Sehingga, Abdurrahman Wahid memperoleh suara yang terbanyak dengan kelebihan 60 suara, sehingga dialah yang menjadi pemenang, sesuai dengan ketentuan yang ada pada Pasal' 6 , ayat (2) UUD 1945 yang berbunyi, "Presiden dan Wakil Presiden dipilih oleh Majelis Permusyawaratan Rakyat dengan suara terbanyak". 'Perlu dicatat, bahwa terdapatnya dua orang calon dalam Pemilihan Presiden 1999 berarti memecahkan "tradisi calon tunggal" yang telah berlaku selama lebih setengah abad.

Dipisahkannya Undang-undang tentang Pemilihan Presiden (dan wakil Presiden) sebenarnya menyalahi aturan Undangundang Dasar. Menurut Pasal 22E, ayat (2), Pemilihan Umum diselenggarakan untuk memilih Anggota DPR, DPD, Presiden dan wakil Presiden, dan DPRD (disebutkan dalam "satu" nafas"). Menurut Pasal 22E ayat (6), ketentuan lebih lanjut tentang Pemilu diatur dengan Undang-undang. Tidak ada perintah (otorisasi) untuk mengatur pemilihan lembaga-lembaga yang disebutkan dalam Pasal 22E, ayat (2), secara terpisah. Jika memang akan diatur secara terpisah, mengapa tidak dibuat Undang-undang tersendiri untuk pemilihan Anggota DPR, DPRD, dan DPD ?. Seharusnya, dalam UU No. 12 Tahun 2003 diatur sekaligus tentang pemilihan Presiden (dan Wakil Presiden), sesuai kemauan Pembuat UUD.

\section{Kelemahan Undang-Undang Pemilu}

Kritik bagi proses Pemilu yang sudah berjalan selama berpuluh-puluh tahun sebelumnya adalah bahwa kedaulatan rakyat kurang dihormati. Memang betul kedaulatan adalah di tangan rakyat, maksudnya rakyat pemilih ("keizerscorps"), hanya berdaulat pada waktu pemilihan umum. Jadi hanya sekali dalam lima tahun. Sesudah itu yang berdaulat atau berkuasa ialah partai politik yang memenangkan Pemilu. Seperti kata Radbruch: "Volksherrsaft bedeutet Partienherrscaft. Wer sich gegen das Bestehen von Parteien wendet, wendet sich gegen die Demokratie" (Kekuasaan rakyat berarti kekuasaan partai. Siapa menentang keberadaan partai, berarti menentang demokrasi). ${ }^{2}$

Sehingga, salah satu hal baru yang dijumpai dalam Pemilihan Umum saat ini, adalah tentang sistem proporsional terbuka. Setelah melalui seminasi wacana publik tentang solusi terbaik untuk mendapatkan wakil rakyat yang berkualitas, disertai juga perdebatan yang cukup panjang dalam. kalangan yang terlibat dengan proses pembuatan undang-undang, akhirnya ; muncullah ketentuan pemilihan wakil rakyat dengan sistem proporsional terbuka ini. Sistem ini memang merupakan sesuatu yang sangat ideal, di mana rakyat akan benar-benar berkesempatan untuk memilih wakilnya secara langsung, tidak harus melewati intervensi pengurus partai. Selama ini, pemilihan dengan sistem proporsional tertutup telah memandulkan apirasi rakyat pemilih, dikarenakan penyusunan daftar Caleg (Calon Legislatif) ada pada pengurus partai, yang sebagaimana telah terbukti,

1 Airasid, Harun, Jabatan Presiden Republik Indonesia, Dies rede pada Sidang Senat Terbuka Dies Natalis ke 56 Universitas Islam Indonesia, 8 Nopember 1999, hal.5

2 Radbruch, Gustav, Vorschule der Rechtphilosophie (Gottingen: Van Derhoeck \& Ruprecht, 1965) hlm. 105 
tidak selalu sejalan dengan kehendak konstituen.

Meski sempat memberikan gairah baru bagi penyelenggaraan Pemilu, namun, dalam kenyataannya, pembuat undang- undang telah melakukan manipulasi terhadap hakekat sistem proporsional terbuka tersebut. Yang dikhawatirkan, dalam Pemilu kali ini pun, sis`em proporsional terbuka itu bisa jadi akan tidak terwujud, atau setidaknya, kehilançan jati dirinya. Hal itu disebabkan adanya kontradiksi antar pasal-pasal dalam UU Pemilu yang baru ini.

Yang perlu ditanggapi ialah ketentuan dalam Pasal 93 dan Pasal 107, UU No. 12 Tahun 2003 yang isinya bertentangan dengan Pasal 6 mengenai sistem proporsional terbuka, yang dalam kepustakaan disebut "sistem pribadi" (Personen stelsel). Sistem pemilihan ini tidak sama dengan "sistem daftar" (lijstenstelsel) yang oleh pembentuk Undang-undang disebut sistem proporsional tertutup.

Menurut sistem daftar, nomor urut calon anggota legislatif (caleg) sifatnya menentukan. Caleg dengan nomor urut kecil (nomor topi) lebih diutamakan (mendapat prioritas), dengan perkataan lain, lebih besar kemungkinan mendapat kursi (terpilih) dari pada caleg yang nomor urutnya besar (nomor sepatu).

Menurut sistem pribadi, nomor urut caleg tidak menentukan. Meskipun mendapat nomor urut besar, namun kalau bisa mencapai.bilangan pembagi pemilihan (BPP) atau disebut juga quota, yaitu suara yang diperlukan untuk memperoleh kursi, maka caleg bersangkutan pasti terpilih.

Ternyata pembentuk Undang-undang "memelintir" pembatasan pengertian (definisi) yang disebut di atas. Dalam Pasal
93, ayat (1), dikatakan bahwa suara yang sah ialah jika pemilih mencoblos (menusuk) tanda gambar partai dan nama caleg pada kolom yang disediakan daiam surat suara (pallot paper). Juga dianggap sah jika pemilih menusuk tanda gambar partai dan tidak -menusuk nama caleg. Jadi, kalau hanya menusuk nama caleg tetapi tidak menusuk tanda gambar partai, maka dianggap tidak sah. Dengan kampanye parpol agar pemilih cukup menusuk tanda gambar parpol, dengan perkataan lain, tidak usah menusuk nama sang caleg atau menusuk orang (person/pribadi), maka hal itu berarti definisi sistem pribadi (yang dalam pasal 6 disebut "sistem proporsional dengan daftar calon terbuka") tidak diterapkan dengan konsekuen. Dengan perkataan lain, masih berlaku sistem proporsional tertutup seperti yang berlaku pada Pemilu 1999. ${ }^{3}$

Perlu juga ditanggapi soal calon terpilih seperti yang diatur dalam Pasal 107, ayat (2). Yang pasti mendapat kursi ialah caleg yang meraih BPP (quota). Bagi yang tidak, maka berlaku nomor urut seperti yang tercantum dalam daftar calon, yang notabene disusun oleh Dewan Pimpinan Pusat (DPP) partai politik. Ketentuan ini tentu akan dirasakan tidak adil bagi caleg yang meskipun tidak mencapai BPP namun mendapat suara yang relatif lebih besar daripada suara yang didapat oleh caleg dengan nomor urut topi. Jadi, dikalahkan oleh caleg yang tidak representatif.

Dengan demikian, apabila diperhatikan, nampaklah bahwa apa yang disebutkan sebagai proporsional terbuka sebenarnyá masih 'semu', karena pada kenyataannya putusan terakhir masih banyak ditentukan oleh pengurus partai dan bukan oleh rakyat.

${ }^{3}$ Editorial Harian Suara Pembaruan, 29 Januari 2004. 


\section{Kesimpulan}

Sudah dapat diantisipasi bahwa DPR hasil Pemilu 2004 akan membentuk perangkat undang-undang pemilihan umum yang baru, atau akan meninjau kembali kedua pasal tersebut dalam menghadapi Pemilu 2009. Namun, layak pula dikritisi dan ditekankan disini bahwa semestinya antara peraturan perundangan yang ada terutama menyangkut Pemilu tidak terjadi inkonsistensi atau kontradiksi substansi, sebagai contoh, sistem proporsional terbuka dan sistem proporsional tertutup itu. Ke depan konsistensi dalam perspektif hukum harus_tidak hanya menyangkut Pemilu senantiasa harus mendapat prioritas untuk ditegakkan, karena hanya dengan konsistensi itu arah ketatanegaraan kita akan berjalan dengan benar (on the track), tidak saling telikung dengan mengabsurdkan substansi hukum dibawah kendali politik.

\section{Daftar Pustaka}

Harun Alrasid, 1999, Jabatan Presiden Republik Indonesia, Dies rede pada Sidang Senat Terbuka Dies Natalis ke 56 Universitas Islam Indonesia.

Gustav Radbruch, 1965, Vorschule der Rechtphilosophie, Gottingen: Van Derhoeck \& Ruprecht.

Suara Pembaruan, 29 Januari 2004. 